\author{
V.V. Savitskyi, post-graduate student \\ V.M. Parshakov, external PhD student \\ Zhytomyr Polytechnic State University
}

\title{
Historical aspects of audit development as a type of economic activity
}

\begin{abstract}
(Presented by Ievdokymov V.V.)
In the course of the research, the scientific literature was analyzed in terms of historical aspects of audit development. The analysis of scientific papers shows that there is no unified approach to audit periodization; this situation has developed due to a combination of objective reasons: the theory underlying the research, the object of research, methods and objectives of the research. Our research was based on the study of historical aspects of business audit in the following order: the origins of audit as an institution of financial control; the formation and evolution of audit in Ukraine (as part of the Russian Empire and the Soviet Union); the emergence of audit and the development of audit in its modern sense; modern trends in audit in the world. During the study it was found that the modern state of audit as an independent financial control and as commercial activity is determined by the external environment of the following aspects: the specific socio-economic relations from the position of the subject of the audit as a tool for independent financial control, specific development management science from the position of introduction of auditing as a tool of the relationship between the management units, development of audit as consulting from a position of auditing as a business. The article investigates institutional support (a set of state, professional and public institutions whose main functions are the regulation of audit and auditing activities) of audit framework of Western European countries.
\end{abstract}

Keywords: accounting; audit; economic activity; analysis; information support; audit activity.

Topicality. The theoretical basis of research in economic specialties (in particular, accounting, economic analysis, audit) is the study of historical aspects of the object of research. The application of the historical approach to scientific research determines the features of the object's evolution in various socio-economic conditions. «The development of audit as a type of practical activity, the improvement of its methodology led to a change in concepts and the formation of its main regulations, which buy the form of conceptual foundations and endue with specific audit theories (police theory, controlling theory, consulting theory). The emergence of these theories is connected not only with the crisis phenomena in the economy, but also with the urgent need to improve audit technology and use qualitatively new concepts» [10].

Issues of the evolution of audit as a professional and economic activity are being updated today from the point of view of identifying its properties, which were manifested at the appropriate stage of the company's development. Nevertheless, audit as a type of business performs a set of socio-economic functions, which are to form the trust of business entities that publish financial statements. The study of the historical background of audit in Ukraine and the world will reveal the reasons for the formation of audit as a special institution of the market economy. According to L.V. Hutsalenko «audit has acquired a separate institute of market economy, which includes requirements of the state and international level and which has certain obligations to the society» [9, p. 349]. Therefore, the application of the historical approach will reveal how audit activity changes in different socioeconomic conditions, which is the basis for taking into account the factors of the internal environment in the economic analysis of the activities of audit firms.

Analysis of recent research and publications. Issues of formation and development of audit at different stages of socio-economic transformations were raised by: L.V. Hutsalenko, Z.O. Dushko, O.A. Petryk, I.I. Pylypenko, H.M. Davydov, T.Kamenska, V.Maksimova, A.N. Kyzylov, I.N. Bohataia, Ph.L. DeFliese, H.R. Jaenicke, V.M. O'Reilly, M.B. Hirsch, M.A. Azarska, S.M. Bychkova, A.V. Hazarian, H.I. Kozlova, M.Yu. Medvedev, T.H. Sheshukova, D.Decker, P.P. Baranov, A.A. Shaposhnikov, V.P. Bondar, N.M. Proskurina and others. The authors considered historical aspects in the context of the transformation of methodological provisions and the development of institutional support. From the point of view of studying the economic activities of audit firms as an object of economic analysis, these aspects are important, because they determine the level of economic potential that the subject of audit activity must correspond at each stage of socio-economic relations.

The purpose of the article is to study the historical aspects of the development of audit as a type of economic activity.

Presentation of basic material. Foreign researcher to the problems of auditing O.S. Lavrenova notes: «Despite the fact that the goals and concepts of audit, which are guided by modern auditors, were almost unknown at the beginning of the XX century, an audit of one type or another was performed throughout the historical record 
of commercial and public finance documents. Originally, the term «auditor» meant «hearer», and this corresponded to an era when government financial reports were approved only after public readings, at which the accounts were read aloud. Since medieval times and before the beginning of the industrial revolution, auditors have established, operated, and reported in a conscientious manner to persons in positions of government or commerce in accordance with their official duties» [13, p. 35].

Sokolov Ya.V. and Bychkova S.M. note that in the historical context, the audit has passed many stages, which determines the variety of theories of its research, in particular, the authors note that «fundamental changes in audit activity, the formation of new theories, the emergence of new approaches to audit and concepts are closely related to financial scandals or economic crises, which highlight the main shortcomings of the audit and require its further improvement. Currently, there are three main audit theories: adequacy theory, controlling theory, and consulting theory» [19].

The historical aspects of audit development have been studied by many scientists but there is no single approach to its periodization. This is due to a set of objective reasons:

- firstly, the theory behind the study. When studying audit, most researchers base their research on a certain theory, which can be related to the theory of the development of science (research) in general (for example, normativism or positivism, institutionalism or neoinstitutionalism); economic theory (for example, stakeholder theory, behaviorism, classical economic and neoclassical economics, and others); social development theory (industrial economy, post-industrial economy, information (digital) economy, the economy of sustainable development of society, and others); the theory of audit itself (police theory, controlling theory, consulting theory);

- secondly, the object of research. Depending on the object of research, the specifics of applying the historical approach is determined. So the object of research can be the audit methodology, and therefore the researcher will study the features of audit methods at different historical stages, which will determine the stages of audit development. Provided that the audit is studied from the point of view of economic activity, the study of historical aspects will take place in the context of the development of consulting as a business sphere at various stages of socio-economic relations. When studying the system of audit regulation, there is a need to study the evolution of the institutions of audit regulation and the entire economic activity.

- thirdly, the methods and objectives of the study. Depending on the tasks of scientific research, the order of applying the historical approach will be determined. In particular, the researcher can offer a periodization of audit development based on the properties of its object, subject, or order of implementation of audit functions.

Studying the scientific literature, we have developed the following approaches to the periodization of audit development. Kizilov A.N., Bogataya I.N. offer their own audit periodization in the context of its main theories (table 1).

Table 1

Stages of audit development in the context of its theories after Kizilov A.M. and Bogataya I.M.

\begin{tabular}{|c|c|c|c|}
\hline Stage & Title & Period & Theory \\
\hline First stage & $\begin{array}{c}\text { Verification } \\
\text { audit }\end{array}$ & $\begin{array}{c}1862-\text { the first quarter of } \\
\text { the twentieth century. }\end{array}$ & $\begin{array}{c}\text { The police theory or the theory of } \\
\text { «watchdog» }\end{array}$ \\
\hline Second stage & $\begin{array}{c}\text { System-oriented } \\
\text { audit }\end{array}$ & $\begin{array}{c}\text { The first quarter of the } \\
\text { twentieth century }-1983 .\end{array}$ & $\begin{array}{c}\text { The theory of controlling, or the theory of } \\
\text { «sniffer dog» }\end{array}$ \\
\hline Third stage & Consulting & $1983-$ present & Consulting theory, or the «guide dog» theory \\
\hline
\end{tabular}

Source: [10]

Thus, the authors identified three fundamental stages of audit development in the context of its theories and tasks. Such audit theories as policing, controlling and consulting correspond to a certain period of socio-economic relations. Economic relations that characterize a particular period of social development determined the main purpose of the audit and, in accordance with this, determined the methodological provisions.

Sultanova K.T. identifies the following stages of audit: «1) by 1500; 2) 1500-1830 (1860); 3) 1830 $(1860)-1905$; 4) 1905-1933; 5) 1933-1940; 6) from 1940 to the present» [21]. However, it does not provide a description of these stages.

Usanova N.G. proposes to consider the evolution of audit in five stages in the context of various socioeconomic relations, as presented in table 2 .

The author's periodization covers not only the development of audit at the present stage, but also the overall development of financial control in a particular country. The author does not provide specific features of the audit either from the point of view of the methodology and tasks or from the point of view of the functioning of the audit subjects. 
Stages of audit development in the context of its tasks and the mechanism for their implementation after Usanova N.G.

\begin{tabular}{|c|c|c|}
\hline Stage & Title & Characteristics \\
\hline First stage & $\begin{array}{c}\text { Appearance of } \\
\text { audit }\end{array}$ & $\begin{array}{l}\text { About } 4000 \text { years ago, the ancient civilizations of the Middle East actively created } \\
\text { states and established economic activities. To account for their income and expenses, } \\
\text { they had to make reports. As a result, this led to the need to organize audits of } \\
\text { accounting components, the main purpose of which was to reduce errors and abuse } \\
\text { by officials. In Athens in the V century B.C., all revenues and expenditures of the } \\
\text { state were controlled by the financial system of people's fees, which included } \\
\text { auditors. In the Roman Republic, public finances were controlled by the Senate, and } \\
\text { auditors under the supervision of the treasurer checked the state budget. The Romans } \\
\text { developed a complex system of checks and cross-checks between officials who were } \\
\text { responsible for collecting taxes }\end{array}$ \\
\hline $\begin{array}{l}\text { Second } \\
\text { stage }\end{array}$ & $\begin{array}{c}\text { Development of } \\
\text { audit }\end{array}$ & $\begin{array}{l}\text { This stage of audit evolution lasted from } 1500 \text { to } 1830(1860) \text {. At that time, the goals } \\
\text { and methods of such control were not changed and consisted in detecting errors and } \\
\text { verifying the integrity of persons responsible for tax payments. Also at that time, the } \\
\text { importance of independent audit of financial statements significantly increased, as } \\
\text { there was a division between the owners of the enterprise into managers and } \\
\text { investors }\end{array}$ \\
\hline $\begin{array}{l}\text { Third } \\
\text { stage }\end{array}$ & $\begin{array}{l}\text { The emergence } \\
\text { of audit in its } \\
\text { modern sense }\end{array}$ & $\begin{array}{l}\text { This stage of audit evolution lasted from } 1862 \text { to } 1905 \text {. This period was characterized } \\
\text { by high economic growth. Very large transactions inevitably led to the foundation } \\
\text { of corporations. This period is also marked by the appearance of the consolidated } \\
\text { balance sheet (1904) }\end{array}$ \\
\hline $\begin{array}{l}\text { Fourth } \\
\text { stage }\end{array}$ & $\begin{array}{l}\text { Changing the } \\
\text { audit task }\end{array}$ & $\begin{array}{l}\text { This stage of audit evolution lasted from } 1905 \text { to } 1940 \text {. Characteristic features of the } \\
\text { audit during this period were the following: the audit were influenced by the New } \\
\text { York stock exchange and government organizations; there was no consensus on the } \\
\text { audit objectives }\end{array}$ \\
\hline Fifth stage & $\begin{array}{l}\text { The emergence } \\
\text { of audit risk and } \\
\text { audit-related } \\
\text { services }\end{array}$ & $\begin{array}{l}\text { This stage of the audit evolution is associated with the complexity of accounting and } \\
\text { an increase in the amount of information to be checked in a certain time frame. This } \\
\text { inevitably led to the need to apply random checks, which eventually became the } \\
\text { basis for the forced assumption of the risk of audit error. The method of restricted } \\
\text { audit was established based on various factors, one of which was the professional } \\
\text { experience of the auditor }\end{array}$ \\
\hline
\end{tabular}

Source: [23]

The proposal for the periodization of audit development presented in the work of M.A. Azarskaya is of interest. This is how the author defines the periodization of audit development in its modern sense as independent financial control. In this context, it is suggested that the audit objectives and main methods should be highlighted at each stage. This allows evaluating the evolution of the audit methodology. The author's suggestions are shown in table 3 .

The evolution of the goals and methods of audit after Azarskaya M.A.

Table 3

\begin{tabular}{|c|c|c|}
\hline Periodization & Audit objectives & Methods \\
prehistory (before 1850) & $\begin{array}{c}\text { Identifying performance and preventing } \\
\text { abuse }\end{array}$ & $\begin{array}{c}\text { Detailed verification of the facts of } \\
\text { economic life }\end{array}$ \\
\hline $\begin{array}{c}\text { The second period-the } \\
\text { emergence of audit } \\
(1850-1905)\end{array}$ & The identification of abuse & $\begin{array}{c}\text { Substantive verification (including testing } \\
\text { of individual elements) }\end{array}$ \\
\hline $\begin{array}{c}\text { The third period - the } \\
\text { formation of the } \\
\text { profession (1905-1933) }\end{array}$ & $\begin{array}{c}\text { Determining whether the client's financial } \\
\text { status is displayed correctly }\end{array}$ & Verification of compliance and substance \\
\hline $\begin{array}{c}\text { The fourth period }- \text { the } \\
\text { formation of the } \\
\text { profession (1933-1940) }\end{array}$ & $\begin{array}{c}\text { Determining the correctness of financial } \\
\text { status; error detection }\end{array}$ & $\begin{array}{c}\text { Testing the accounting and internal control } \\
\text { system }\end{array}$ \\
\hline $\begin{array}{c}\text { Fifth period-current state } \\
(1940-\text { present) }\end{array}$ & $\begin{array}{c}\text { Identifying the effectiveness of internal } \\
\text { control }\end{array}$ & $\begin{array}{c}\text { Standardization of audit processes } \\
\text { misstatement of financial statements, identification of in-house reserves. It is characterized by } \\
\text { the transition from the audit of financial statements to the audit of business. Distinctive features } \\
\text { are the use of a risk-based approach and the provision by auditors of a wide range of audit- } \\
\text { related and other services related to audit activities }\end{array}$ \\
\cline { 2 - 3 }
\end{tabular}


These proposals prove a multi-dimensional periodization of the development of the audit. In our study, we do not aim at evolving a periodization of audit development, we only try to assess its properties at each stage of social promotion from the perspective of audit entities as business entities.

The origins of audit as a type of financial control date back to ancient times. The first manifestations of control activity can be traced in the countries of the ancient world, i.e. India, Egypt, Babylon, China. «In the Ancient East, there were rudiments of control over the activities of accountants. The ancient Egyptians, Chinese, and Sumerians monitored the activities of officials. The history of audit as an economic phenomenon goes back centuries. Elements of control were used in Ancient Babylon, where approximately 5,000 years ago clay tablets were used, which were auditor-confirmed reports. During the Middle Kingdom of the Nile, a representative of the Pharaoh supervised the storage of grain. Audit in those days consisted of observing, counting and re-examining reports» [10]. The specifics of auditing in India are defined by the provisions of «Arthashastra, or the science of politics», which is the science of government, which provides for separate provisions for maintaining accounts in the accounting department.

Sokolov Ya.V. points out that «elements of audit activity were used in Babylon and Ancient Egypt in assessing the correctness of tax collection, in the middle ages - in the sphere of trade. In the Ancient world, public legal reporting took place. According to Herodotus, there was carved on the pyramid of Cheops how much garlic, radishes, onions and other products were given to people engaged in the construction of the pyramid, the total cost of which is 1500 talents. We have reached a report carved on the wall of the Parthenon, according to which the cost of construction was 469 talents» [18, p. 31]. «Some scientists believe that in China, the first audit system was created in 700 B.C. In China during the Zhou dynasty (1122-256 B.C.) the state system had a balanced budget, and all government companies were audited. However, the ancient auditors were usually civil servants, and the independence of the audit was out of the question» [10]. To a greater extent, the need for control was related to the functioning of the state treasury and the payment of taxes. Thus, Golyash I.D. believes that «the historical facts of the slave-owning world serve as the basis for understanding audit as one of the procedures of economic control, but not as an independent profession» [8].

In the Ancient era, audit as an institution of financial control had the following features in:

- Greece. «In Greece, in the V century B.C., there was a system of control of income and expenditure by the People's Assembly, and the financial system included government auditors who checked the documents of all officials at the end of their powers ... Famous Greek philosophers paid due attention to accounting and control. Thus, Aristotle in «Politics» clearly distinguished accounting and control functions, and considered audit as part of control» [11, p. 62-63].

- Rome. «In the Roman Empire from the seventh century B.C., control functions were performed by curators, procurators, quaestors, who controlled public accountants in the field» [16, p. 50]. «In Ancient Rome, the purpose of accounting was mainly to control economic activity and pay taxes. A complex apparatus of auditors and supervisors was created, and yet the facts of fraud and tax evasion were not isolated. Audit was to prevent the losses which arose as a result of fraud or inability to farm. During the middle ages, along with the development of socio-economic relations, accounting and control of economic activities were improved, and special treatises appeared on the control of accounting and reporting, which currently performs audits. Control becomes the main tool for preserving private property, so in the twentieth century the main function of accounting was purely control» [14].

Thus, the Ancient world is the source of audit from the position of the main purpose of -controlling economic activity (mainly the state treasury), as well as the formation of the audit profession. «The Medieval era is characterized by slow development of audit. After the collapse of the Roman Empire due to the expansion of foreign trade, audit continued to develop in Venice, Florence, and Genoa. The main goal of auditors at that time was to control the correctness of accounting. In Europe, audit at that time was not widely used, only in the UK and France, the audit system continued to be formed, the main purpose of which was to control the payment of taxes, the formation and expenditure of public funds» [8].

However, audit in the modern sense appeared much later in the UK. «It should be noted that in the modern sense, audit originated in the UK when the regulatory framework was created and the principle of independence was fully established as one of the fundamental principles of audit. In 1862, the law on mandatory audit was adopted, and audit was recognized as a separate branch of economic science. However, by 1862 , there are references to audit as a form of practical activity, about its individual techniques that are still used today» [10]. «The birthplace of modern audit is England. As early as the 9th century, an impetus was given to «account and measure» in British economic life, when the long-standing cults and accounting techniques of the Romans, preserved in the country and in Normandy, received a new everyday application to the accounting of economic phenomena. Even at that time, the related concept of «auditor» was distinguished from the general concept of «accountant». For the first in its daily activities, the functions of the person organizing and leading the accounts are preserved, and the second is assigned self-sufficient independent functions of the controller, checking the accounts» [21]. 
However, the first mention of audit in the UK was almost 7 centuries earlier, namely in 1130, which was established based on a study of the archives of the treasury of England and Scotland. Foreign teachings by Ph.L. DeFliese, H.R. Jaenicke, V.M. O'Reilly, M.B. Hirsch indicate that «the city of London was audited in the $1200 \mathrm{~s}$. At the beginning of the fourteenth century, auditors were also among the elected officials. The archives of that period contain a lot of documents testifying to the wide recognition of the importance of audit and regular audit of reports of municipalities, private landholdings and craft guilds» [3, p. 23].

In turn, domestic scientists I.D. Golyash and L.A. Budnik note that «the renewed interest in audit is characterized by the appearance of information about it in the UK at the beginning of the XII century. But only in the XIII century audit received state recognition, which is confirmed by the publication in 1285 of the world's first legislative act regulating audit activities. The history continued with the signing of a decree in 1324 appointing three state auditors, which indicates a significant revival of interest in audit. Since that time, the formation of independent audit in its modern sense has begun» [8].

Similar historical provisions are contained in the work of Ya.V. Sokolov «The first legislative act regulating the activities of auditors was a law drawn up in 1285 by king Edward I of England. According to this law, auditors on behalf of the state were not only persons from among the trusted servants of the lords, but also certain categories of civil servants, and all were granted certain privileges. Thus, the first rudiments of applying the principle of independence in audit appear. King Edward II signed a decree on March 24, 1324 appointing three state auditors whose duties included checking accounts. They were charged with taking all accounts that had been introduced and that would be introduced in the provinces of Oxford, Birkenhead, Southampton, Wales, Somersetshire, and Dorset, «to do and mark all that the auditors of accounts should do» [18].

However, the prototype of the modern regulated independent audit originated in 1844 «in England, mandatory audit was introduced in accordance with a number of adopted company laws, which required the boards of jointstock companies to invite (at least once a year) a specialist to check the verification of accounts and mandatory reports to shareholders» [10]. «The most important milestone in the history of the formation of audit activity as a mandatory form of control was the publication in 1862 in the UK of the law on British companies (the Companies Act 1862), which proposed mandatory audit of accounts and reports of companies by auditors at least once a year. In addition, at the end of the XIX century, many European countries formed professional communities (institutions) of accountants and auditors, as well as legislative acts providing for mandatory annual independent audit of the company's financial statements and providing the results of such audits to shareholders» [20].

The British practice of audit development put a certain imprint on its formation in Germany and the United States, in particular; in the United States, audit activity developed under the influence of British audit practice, «when English railway workers, insurance companies and other investors went to North America, along with them went independent auditors to protect the interests of large English creditors» [2]. This practice continued until the twentieth century. «In 1896, the state of New York legislated that the position of auditor could be held by a certified accountant who successfully passed the exam in the specialty at New York University and received a special license to engage in auditing» [7]; in Germany, based on the experience of the development of English audit in 1884 , the Institute of accountants-auditors was established. However, as early as 1870, «an addendum to the law on joint-stock companies was adopted that required the supervisory boards of these companies to check the balance sheet, report on the distribution of profits and report on the results of the audit at general meetings of shareholders, without specifying whether such an audit should be carried out by their own (internal) auditors or invited from outside» [7, p. 65]. It should be noted that the main impetus for the formation of the concept of independent audit in Germany was the Gruender fever, which became a prerequisite for the collapse of joint-stock companies.

Historical aspects of development in Ukraine are more closely related to the features of the financial control system in the Russian Empire, and later in the Soviet Union.

«The audit was introduced by Peter I, but essentially it was a state financial control of a narrow focus in the field of property relations in the army. As an independent form of control, audit was not formed in the Russian Empire. For the purpose of developing the profession, attempts were made to conduct examinations in 1888, 19071912. However, if it was necessary to conduct an audit in the Russian Empire, foreign auditors were invited. There was no regulation of audit activity on the part of state bodies, but the provisions regulating audit activity, that were adopted in other countries, were used. After October 1917, the need for audit, as a form of commercial activity, disappears, as the nationalization of economic entities was carried out and financial control becomes fully state. NEP revived audit control for a short time, which was due to the emergence of commercial organizations» [22].

«Further on, several more attempts were made to create an Institute of audit in Russia, so in 1891 the 1 st Congress of accountants was held, at which they announced the opening of the Society of accountants. Its primary task was to form a group of «sworn accountants» who were entrusted with the audit of various accounting, examination and organization of correct accounting in private and public enterprises. But this initiative did not find understanding and support in the professional environment. The main obstacle was the rejection of the requirement of confidentiality (the auditor can not report violations to anyone other than the client) and the very essence of the relationship between the organization and the auditor (the auditor not only checks financial 
documents, but also describes the identified shortcomings and violations in the act). For this and a number of other reasons, the project to establish the Institute of accountants and sworn accountants was never approved by the State Council» [17]. By its nature, the position of auditor was different from the similar position in Western Europe, since in Russia, auditors were lawyers who combined the functions of clerk, secretary and prosecutor in their activities [15].

«Another attempt to develop audit activity was made already in the Soviet Union, during the NEP, when in 1925 the Institute of state accountants-experts (ISAE) was created under the People's Commissariat of the Workers' and Peasants' Inspectorate of the USSR. The Institute was created to promote and correct accounting and reporting in state, concession, mixed, cooperative, public and private enterprises and public institutions. Thus, the task of this institution was defined as the promotion of correct accounting in the country and the conduct of examinations on all kinds of accounting and reporting issues at the request of state bodies. The activities of the Institute were closed, since all the material accumulated in the course of work was submitted in the form of conclusions and reports to the Central bureaus of the ISAE, and then sent to the storage facilities. Accordingly, all the detected shortcomings and achievements in the field of accounting and reporting were not published» [17]. Later in the Soviet Union, audit as an independent type of financial control did not develop. All control functions were assigned to state control bodies. It was only during the period of restructuring (perestroika) and independence of the republics of the Soviet Union, which prompted market relations, that audit in its modern sense began to emerge, following examples of best practices in Western countries.

Baranov P.P., describing the origins of modern trends in the development of audit as an instrument of independent financial control and as a type of economic activity in the consulting sphere, indicates that «the appearance and intensive expansion of audit activities in Western Europe in the XIX century were the result of the so-called fourth management revolution, in which there was a separation of management from property and the formation of a community of professional managers. Separation of business owners from the actual business and processes of information characterizing the effectiveness of the latter, gave rise to an objective conflict of interests between owner and manager, due to the traditional approach to motivation, managers have linked the effectiveness of the managerial labor efficiency control object. Exploitation of such a model of motivation, on the one hand, is almost inevitable, but, on the other hand, it creates a fertile ground for veiling and falsifying accounting financial statements, analyzing which the owner makes conclusions about the financial and property status of the business unit belonging to him, the results of its economic activities and makes, among others, the most important decision for the manager, i.e. the decision on the size and form of his remuneration. Overcoming this contradiction was impossible without the appearance of a third entity in the «owner-manager» bundle - an independent auditor, who is called upon to evaluate the reliability of economic information using special methods, to assign management to the form of accounting financial statements and used by owners in forming their line of behavior regarding the business they own» [4].

The author's statement indicates that audit as a type of business is characterized by significant variability to environmental factors. We believe that the current state of audit as a type of independent financial control and as a type of economic activity is determined by the external environment from the following positions:

- firstly, the specifics of socio-economic relations from the position of the object of audit as an instrument of independent financial control;

- secondly, the specifics of the development of management science from the point of view of the appearance of audit as a tool for the relationship between management links;

- thirdly, the development of audit as consulting from the position of audit activity as a type of business.

The current state of audit as a type of independent financial control and as a type of economic activity in various countries of the world is characterized by a certain state of socio-economic relations. Studying the current state of audit development and activities of audit firms in the countries of the world, first of all, it is worth noting the trends towards unification of the process of regulating audit and auditing activities. This is especially true in the European Union «Modern international audit is characterized by the fact that almost all developed countries of the world have a public Institute of professional audit, which has its own legal and organizational infrastructure. But there are also differences in the state control of audit activities. Audit firms in the UK are characterized by great independence in terms of training, qualification, and quality control of professional duties performed by auditors. Audit activities in the countries of continental Europe are strictly regulated by the state. Audit in the European Union is regulated by legal acts adopted by government authorities. In these countries, along with auditors engaged in checking accounting reports and balance sheets, there is a specific category of auditorsconsultants on tax issues» [12, p. 341].

«Currently, the legal regulation of audit is significantly influenced by the processes related to the economic integration of EU countries, which provide for the unification of accounting and audit practices. In particular, the regulation of audit activities is devoted to Directive 2014/56 / EU of the European Parliament and of the Council of April 16, 2014 on amending Directives 2006/43 / EU with mandatory audit of annual accounts and consolidated statements, Regulation EU № 537/2014 of the European Parliament and of the Council of April 16, 2014 on special 
requirements for mandatory audit of public interest entities and repealing Decision 2005/909 / EC of the European Commission and Directives 89/48 / EEC and 92/51 / EEC on mutual recognition of professional qualifications in all EU member states, as well as in Norway, Iceland and Liechtenstein» [6, p. 126].

Based on the study of scientific, educational, reference literature and legal acts and analytical reports, we will present the specifics of the regulation of audit activities in Western European countries, as the economic development, political and legal systems and participation in international associations are in different groups. Features of institutional support for audit activities in Western Europe are presented in table 4.

Institutional support for audit regulation in Western European countries

\begin{tabular}{|c|c|}
\hline Country & Audit regulatory bodies \\
\hline France & $\begin{array}{l}\text { Chamber of accounting experts } \\
\text { National company of account commissioners }\end{array}$ \\
\hline Italy & Justice Department \\
\hline Bulgaria & Institute of chartered expert accountants \\
\hline Germany & $\begin{array}{c}\text { Audit chambers } \\
\text { Institute of auditors } \\
\text { Federal Ministry of Economy }\end{array}$ \\
\hline Poland & $\begin{array}{c}\text { National Board of Auditors } \\
\text { Special National Congress of Professional Auditors } \\
\text { National Room of the Auditors }\end{array}$ \\
\hline Belarus & $\begin{array}{l}\text { The Union of auditors } \\
\text { Audit chamber }\end{array}$ \\
\hline Lithuania & $\begin{array}{l}\text { Lithuanian Association of accountants and auditors (LAAA) } \\
\text { Audit Chamber of Lithuania }\end{array}$ \\
\hline Moldavia & $\begin{array}{c}\text { The Council for supervision of auditing activities under the Ministry of Finance } \\
\text { Professional non-governmental organizations }\end{array}$ \\
\hline Belgium & Belgian Institute of registered auditors \\
\hline Greece & $\begin{array}{l}\text { Institute of certified auditors of Greece } \\
\text { Accounting and Audit Supervisory Board }\end{array}$ \\
\hline Ireland & $\begin{array}{l}\text { Institute of chartered accountants of Ireland } \\
\text { Institute of chartered accountants of England and Wales } \\
\text { Irish audit and accounting supervisory authority }\end{array}$ \\
\hline
\end{tabular}

By institutional support, we mean a set of state, professional and public institutions which main functions are to regulate audit and auditing activities.

Table 5 shows the specifics of the audit regulation system in Western European countries such as Belgium, Greece and Ireland.

Modern system of regulation of auditing activity in the countries of Western Europe

\begin{tabular}{|c|c|c|}
\hline Belgium & Greece & Ireland \\
\hline 1 & 2 & 3 \\
\hline \multicolumn{3}{|c|}{ Regulatory authorities } \\
\hline $\begin{array}{l}\text { Belgian Institute of registered } \\
\text { auditors }\end{array}$ & $\begin{array}{l}\text { Institute of certified auditors of } \\
\text { Greece Audit } \\
\text { Accounting and A Aupervisory Board } \\
\text { Sula }\end{array}$ & $\begin{array}{l}\text { Institute of chartered accountants of Ireland } \\
\text { Institute of chartered accountants of England } \\
\text { and Wales } \\
\text { Irish audit and accounting supervisory } \\
\text { authority }\end{array}$ \\
\hline \multicolumn{3}{|c|}{ Purpose of regulatory authorities } \\
\hline $\begin{array}{l}\text { IBR-IRE compiles audit } \\
\text { standards, and the Council of State } \\
\text { for economic professions } \\
\text { approves them. IBR-IRE monitors } \\
\text { the quality of audit activities }\end{array}$ & $\begin{array}{l}\text { Monitoring the activities of } \\
\text { auditors registered in SOE, } \\
\text { controlling compliance with } \\
\text { legislation, professional and } \\
\text { ethical norms and standards by } \\
\text { auditors }\end{array}$ & $\begin{array}{l}\text { Monitoring the work of auditors included in } \\
\text { the register, the registration process of } \\
\text { external auditors, monitoring their } \\
\text { compliance with legislation in the field of } \\
\text { audit }\end{array}$ \\
\hline
\end{tabular}


ISSN 1994-1749. 2020. Bun. 2 (46)

Проблеми теорії та методологї бухгалтерського обліку, контролю і аналізу

End of the table 5

\begin{tabular}{|c|c|c|}
\hline 1 & 2 & 3 \\
\hline \multicolumn{3}{|c|}{ Application of mandatory audit } \\
\hline $\begin{array}{l}\text { Companies that exceed two of the } \\
\text { three criteria two years } \\
\text { successively: annual turnover }- \\
7.3 \text { million euros); assets }-3.65 \\
\text { million euros; number of } \\
\text { employees - } 50 \text { people. } \\
\text { Companies with more than } 100 \\
\text { employees. Subsidiary companies. } \\
\text { Companies which Standing orders } \\
\text { require mandatory audit }\end{array}$ & $\begin{array}{l}\text { Organizations that exceed two of } \\
\text { the three limits: total assets }-4 \\
\text { million euros, net turnover }-8 \\
\text { million euros, average number of } \\
\text { employees }-50 \text { people }\end{array}$ & $\begin{array}{l}\text { Public companies. Companies that exceed } \\
\text { one of the conditions (for the current and } \\
\text { previous financial year): turnover }-8.8 \\
\text { million euros, assets }-4.4 \text { million euros at } \\
\text { the end of the financial year, the average } \\
\text { number of employees }-50 \text {. Companies to } \\
\text { which the amendment of } 1986 \text { does not } \\
\text { apply. Parent or subsidiary companies }\end{array}$ \\
\hline \multicolumn{3}{|c|}{ Requirements for auditors } \\
\hline $\begin{array}{l}\text { Meet the requirements of } \\
\text { education and certification. The } \\
\text { IBR-IRE member has the right to } \\
\text { provide its services (license). } \\
\text { Auditors are appointed by the } \\
\text { shareholders on the proposal of the } \\
\text { audit committee, if any }\end{array}$ & $\begin{array}{l}\text { Included in the register of auditors; } \\
\text { legislation, professional and } \\
\text { ethical standards are observed. } \\
\text { The regulatory auditor or audit } \\
\text { firm is appointed by the general } \\
\text { meeting of shareholders of the } \\
\text { audited entity }\end{array}$ & $\begin{array}{l}\text { Member of a professionally recognized } \\
\text { professional organization. Registration of an } \\
\text { audit firm in ICAEW allows working in both } \\
\text { the UK and Ireland }\end{array}$ \\
\hline \multicolumn{3}{|c|}{ Rotation of auditors } \\
\hline $\begin{array}{l}\text { Auditors are appointed for three } \\
\text { consecutive years, with a } \\
\text { maximum period of nine years. } \\
\text { The cooling period is two years }\end{array}$ & $\begin{array}{l}\text { Auditors may offer their services } \\
\text { for a period of search work not } \\
\text { exceeding five consecutive years } \\
\text { and restore their duties after the } \\
\text { expiration of two consecutive years }\end{array}$ & $\begin{array}{l}\text { Currently, the requirements for rotation are } \\
\text { not defined }\end{array}$ \\
\hline \multicolumn{3}{|c|}{ Requirements for the audit report } \\
\hline
\end{tabular}

Source: developed on the basis of [6]

Similar and at the same time different trends are observed in other countries of the world. Thus, the United Kingdom and the United States are a kind of «trendsetters» in the field of audit, which is associated with the functioning of the largest securities markets on their territory: London stock exchange and New York stock exchange. We have reviewed the works of scientists who characterize the development of audit as a type of professional and economic activity in the countries of the world, in particular in Asia:

- Kazakhstan. «Audit services in Kazakhstan are developing rapidly, although there are problems in their application. The solution of problems is influenced by the increase in competitors in the market of audit services, that is, the number of auditors is increasing, and therefore you need to have a high awareness in this area to have regular customers who would be happy with the work of the auditor. Currently, there are only 500 auditors in Kazakhstan as part of 129 audit organizations for about 8 thousand enterprises of public interest, there are about 5 thousand of certified auditors and about 3 thousand audit entities that are included in the register of audit firms and auditors. At the same time, the registry has about 0.5 thousand companies and 2.5 thousand private entities of auditors-entrepreneurs. The total volume of the audit services market is estimated at 80 million dollars for a year or about 4.1 thousand dollars per certified auditor. Also, the problem is the insufficient number of qualified audit personnel, which entails not mastering the market of audit services» [21];

- The Republic of Korea (the informal name of -South Korea). «With the increase in international trade and attracting international investment to Korea, the need for effective external audit systems is growing. In 1980, the law on external audit was adopted, which required corporations with certain acts to undergo mandatory audits with the help of external auditors. The most important documents in the field of regulating the activities of the external auditor are the International standards on auditing adopted in the Republic of Korea, adjusted in accordance with the Korean specifics, referred to as the KSA - Korean standards on auditing. There are a number of differences between international and Korean auditing standards. However, at present, it is only possible to get acquainted with the Korean audit standards in Korean or English» [5]. 
Conclusions and prospects for further research. Analysis of the current stage of development of audit activity in the world indicates the lack of unified global approaches to audit regulation. Each company develops its own approaches to providing guidance on audit regulation and sets specific requirements for the firm's audit activities. It is worth noting that the main characteristic of modern audit is the establishment of requirements for the actual human resources of the audit firm. The prospects for further research are the study of the assessment of economic resources in the economic activities of audit firms as an object of economic analysis.

\section{References:}

1. Azarskaya, M.A. (2009), Metodologiya i razvitie metodicheskogo obespecheniya ego kachestva, OOO «String», Ioshkar-Ola, $195 \mathrm{p}$.

2. Andreev, V.D. (1994), Prakticheskii audit, Ekonomika, Moscow, 366 p.

3. Defliz, F.L., Dzhenik, G.R., Reilli, V.M. and Khirsh, M.B. (1997), Audit Montgomeri, Audit, YuNITI, Moscow, $542 \mathrm{p}$.

4. Baranov, P.P. (2013), «K voprosu o neobkhodimosti formirovaniya nauchnoi teorii audita», Vestnik NGUEU, No. 4, [Online], available at: https://cyberleninka.ru/article/n/k-voprosu-o-neobhodimosti-formirovaniya-nauchnoy-teorii-audita

5. Vasilenko, M.E. and Zadvornyi, A.S. (2017), «Spetsifika koreiskikh standartov audita v kontekste rossiiskoi i mezhdunarodnoi praktiki», ANI: ekonomika $i$ upravlenie, No. 2 (19), [Online], available at: https://cyberleninka.ru/article/n/spetsifika-koreyskih-standartov-audita-v-kontekste-rossiyskoy-i-mezhdunarodnoypraktiki

6. Voloshina, E.I. (2017), «Osobennosti auditorskoi deyatel'nosti v stranakh Zapadnoi Evropy», Nauchyi vestnik: Finansy, banki, investitsii, No. 3, pp. 124-130.

7. Voronina, L.I. (1999), Osnovy sovremennogo bukhgalterskogo ucheta i audita, ucheb. posobie in 2 p., Osnovy audita, Part 2, Moscow, 304 p.

8. Goljash, I.D. and Budnyk, L.A. (2016), «Tendencii' rozvytku audytu: retrospektyvnyj pogljad ta proekcija na majbutnje», Naukovyj visnyk Hersons'kogo derzhavnogo universytetu, Serija Ekonomichni nauky, No. 17 (1), pp. 130-133.

9. Gucalenko, L.V. and Marchenko, S.O. (2016), «Realii' audytu u vitchyznjanij ta zarubizhnij praktyci», Buhgalters'kyj oblik, analiz ta audit, No. 6, pp. 34-354.

10. Kizilov, A.N. and Bogataya, I.N., «Evolyutsiya audita kak nauki i prakticheskoi deyatel'nosti», Mezhdunarodnyi bukhgalterskii uchet, No. 34, [Online], available at: https://cyberleninka.ru/article/n/evolyutsiya-audita-kak-nauki-iprakticheskoy-deyatelnosti-1

11. Kuzhel'nyi, N.V. (1985), Bukhgalterskii uchet i ego kontrol'nye funktsii, prakticheskoe rukovodstvo, Finansy i statistika, Moscow, 143 p.

12. Kucherov, A.V. and Kozicheva, Ya.M. (2013), «Osobennosti audita za rubezhom», Molodoi uchenyi, No. 5, pp. 339-343.

13. Lavrenova, E.S. (2016), «Osobennosti razvitiya audita v istoricheskom aspekte s tochki zreniya amerikanskoi ekonomiki», Juvenis scientia, No. 5, pp. 34-36.

14. Lebedjev, O.P., «Istorychni aspekty zarodzhennja ta rozvytku kontrolju finansovoi' sfery krai'ny», [Online], available at: http://adminpravo.com.ua/index.php/2010-04-13-14-05-13/61-2010-07-08-14- 15-02/701-11-.html

15. Makoed, I.A. and Pupko, G.M. (2009), Audit: in 2 p., Part 1, NIU, Minsk, 227 p

16. Mel'nychuk, B.V. (2011), «Evoljucija sutnosti audytu», Ekonomika APK, No. 12, pp. 49-57.

17. Pimenov, D.M. (2013), «Analiz i obobshchenie istoricheskikh aspektov razvitiya audita v Rossii», Vestnik Moskovskogo universiteta MVD Rossii, No. 9, pp. 292-302.

18. Sokolov, Ya.V. (1991), Ocherki po istorii bukhgalterskogo ucheta. Finansy i statistika, Moscow, $400 \mathrm{p}$.

19. Sokolov, Ya.V. and Bychkova, S.M. (1998), «Rol' teorii audita v protsesse podgotovki kadrov», Auditorskie vedomosti, No. 2.

20. Stepanova, Ya.V. Zadachi audita: evolyutsiya $i$ perspektivy, [Online], available at: https://cyberleninka.ru/article/n/zadachi-audita-evolyutsiya-i-perspektivy

21. Sultanova, K.T. (2019), «Tendentsii razvitiya auditorskoi deyatel'nosti v Kazakhstane», Pedagogicheskaya nauka $i$ praktika, No. 3 (25), [Online], available at: https://cyberleninka.ru/article/n/tendentsii-razvitiya-auditorskoydeyatelnosti-v-kazahstane

22. Toropova, I.S. (2017), «Audit v Rossiiskoi Federatsii: istoriya razvitiya i sovremennoe sostoyanie», Nauchnyi vestnik: finansy, banki, investitsii, No. 4 (41), pp. 153-157.

23. Usanova, N.G, Istoriya razvitiya audita, [Online], available at: http://www.buk.irk.ru/library/sbornik_03/6.shtml

Savitskyi Vladyslav - postgraduate student of Department of Accounting and Auditing, Zhytomyr Polytechnic State University.

Scientific interests:

- economic analysis of audit firms' activities.

Parshakov Valerii - external PhD student of Department of Accounting and Auditing, Zhytomyr Polytechnic State University.

Scientific interests:

- peculiarities of audit firms' activities. 